Original article

\title{
FIRST REPORT ON ASIAN FISH TAPEWORM (BOTHRIOCEPHALUS ACHEILOGNATHI) INFECTION OF INDIGENOUS MAHSEER (TOR TAMBRA) FROM NAGAN RAYA DISTRICT, ACEH PROVINCE, INDONESIA
}

\author{
Z. A. MUCHLISIN ${ }^{1}$, Z. FUADI $^{1}$, A. M. MUNAZIR ${ }^{1}$, N. FADLI ${ }^{1}$, \\ W. WINARUDDIN ${ }^{2}$, C. NANDA DEFIRA ${ }^{3} \&$ A. HENDRI ${ }^{4}$ \\ ${ }^{1}$ Department of Aquaculture, Faculty of Marine and Fisheries, Syiah Kuala Univer- \\ sity, Indonesia; ${ }^{2}$ Faculty of Veterinary Medicine, Syiah Kuala University, Indonesia; \\ ${ }^{3}$ Department of Biology, Faculty of Sciences, Syiah Kuala University, Indonesia; \\ ${ }^{4}$ Faculty of Marine and Fisheries, Teuku Umar University, Meulaboh, Indonesia
}

\section{Summary}

Muchlisin, Z. A., Z. Fuadi, A. M. Munazir, N. Fadli, W. Winaruddin, C. Nanda Defira \& A. Hendri, 2015. First report on Asian fish tapeworm (Bothriocephalus acheilognathi) infection of indigenous mahseer (Tor tambra) from Nagan Raya district, Aceh province, Indonesia. Bulg. J. Vet. Med., 18, No 4, 361-366.

The aim of the present study was to examine the prevalence and intensity of the Asian fish tapeworm, Bothriocephalus acheilognathi on the indigenous mahseer fish Tor tambra. The fish samples were collected from Isiep River, Nagan Raya District as representative of wild population and from aquaculture ponds as representative of captive population. A total of 30 fish samples from Krueng Isep river and 30 fish samples from aquaculture fish ponds were examined in this study. The fish samples were abdominally dissected and the alimentary tracts were taken and perforated. The alimentary contents were placed onto Petri dish and observed for tapeworms. The samples of worm were photographed using stereo microscope. The results showed that the fish samples from aquaculture fishponds were infected by Bothriocephalus acheilognathi with the prevalence and intensity of $53.33 \%$ and 8.06 , respectively, while no fish from the river was infected by cestoda.

Key words: Bothriocephalus acheilognathi, cestodes, intensity, keureling, prevalence

\section{INTRODUCTION}

Keureling fish or internationally named mahseer (Tor tambra) is one of the popular freshwater fish in Indonesia. The fish has a good taste and higher price in local and regional markets (Muchlisin et al. 2015). At present, the spawning of this species has been successfully induced and it is experimentally cultured in the pond. However, the keureling fish in captive conditions is very susceptible to parasites infestation. Muchlisin et al. (2014) reported that about $50 \%$ of keureling popula- 
tions in aquaculture ponds were infected by Lernea sp., Argulus sp. and Trichodina sp. In addition, the preliminary field observation revealed that the cultured mahseer was also infected by cestodes of the Asian fish tapeworm, Bothriocephalus acheilognathi. Hence, this is the first report on the Asian fish tapeworm infection from western part of Indonesia.

The Bothriocephalus acheilognathi was first described in Japan from intestine of Acheilognathus rhombea (Yamaguti, 1934) and currently is the common endoparasite for freshwater fish worldwide, particularly cyprinids (Marcogliese, 2008; Choudhury \& Cole, 2011). This worm has been reported to infest fish in the USA (Heckmann et al., 1993; Scholz, 1997; Kuperman et al., 2001), Europe (Marcogliese, 2008) and other parts of the world, koan fish in Iran (Hosseinifard et al, 2011), some native freshwater fish species in Mexico (Salgado-Maldonado \& Pineda-Lopez, 2003). According to Choudhury et al. (2013) the grass carp, Ctenopharyngodon idella could be considered a principal host for $B$. acheilognathi in $\mathrm{Pa}$ nama and worldwide. Nowadays this parasite has been categorised as global freshwater invasive species due to the success of invasiveness; however, no report from Indonesia was available. According to Ozturk \& Ozer (2014) the wide spread of Asian tapeworm has occurred in two ways; import-export of exotic cyprinids for culture and introduction of grass carp for controlling macrophytes in different region throughout the world (Boomker et al., 1980).

In general, besides infecting fish, the cestodes are also likely to infect humans consuming the infected and improperly cooked fish (Justine et al., 2012; Yera et al., 2013). Some species of cestodes infect men for long period without any symp- toms (Waeschenbach et al., 2012). The objective of the present study was to evaluate the prevalence and intensity of $B$. acheilognathi infection on local mahseer fish from wild and captive population in Nagan Raya District, Indonesia. This is the first report for infection of Bothriocephalus acheilognathi in freshwater fish from Aceh region, Indonesia.

\section{MATERIALS AND METHODS}

\section{Study site and time}

The study was conducted in Beutong Subdistrict, Nagan Raya, Aceh Province, Indonesia from December 2013 to February 2014. The wild population sample was collected from Isiep River $\left(04^{0} 16^{\prime} 51.61^{\prime}\right.$ N, $96^{0} 26^{\prime} 58.53$ 'E), while captive fish were collected from aquaculture ponds $\left(4^{0} 14^{\prime} 50.53^{\prime}, \mathrm{N}, 96^{0} 26^{\prime} 13.48^{\prime}\right.$ ' $\left.\mathrm{E}\right)$ in Meunasah Krueng village of Nagan Raya. The laboratory analyses were carry out in Syiah Kuala University and Brackishwater Aquaculture Station, Ujung Batee in Banda Aceh and Aceh Besar, respectively.

\section{Sampling}

Samplings were conducted during the rainy season, December 2013. A total of 60 fish were collected randomly from wild (30 individuals) and captive (30 individuals) populations using casting nets with two mesh sizes (1.0 and 2.0 inches). Collected fish were preserved in ice box $\left(4{ }^{\circ} \mathrm{C}\right)$ until transported to laboratory for further analysis. The main water quality parameters such as dissolved oxygen, $\mathrm{pH}$, temperature and turbidity were measured ex situ.

\section{Sample preparation and analysis}

The fish samples were anaesthetised in a solution of tricaine methanesulfonate (MS 222), prepared by dissolving $4 \mathrm{~g}$ of $\mathrm{MS}$ 
Table 1. Prevalence and intensity of Asian fish tapeworm Bothriocephalus acheilognathi in the alimentary tract of keureling fish (T. tambra) collected from wild and captive systems

\begin{tabular}{lcc}
\hline \multirow{2}{*}{ Parameters } & \multicolumn{2}{c}{ Populations } \\
\cline { 2 - 3 } & Captive $(\mathrm{n}=30)$ & Wild $(\mathrm{n}=30)$ \\
\hline Total number of infected fish & 16 & - \\
Total number of tapeworms & 129 & - \\
Intensity & 8.06 & - \\
Prevalence (\%) & 53.33 & - \\
\hline
\end{tabular}

222 in $5 \mathrm{~L}$ tap water (Muchlisin et al., 2004) measured for total length (cm) and body weight $(\mathrm{g})$, and then submitted to abdominal dissection using sterile scissors. The alimentary tract were removed, placed into a jar then perforated with a needle and the alimentary contents were placed onto Petri dish and observed for Asian tapeworm cestodes naked-eye or using a magnifying glass. The samples of worm were taken from the Petri dish, placed onto object glass and two drops of safranin were added to the sample for observation under stereo microscope (40$100 \times$ magnification) and photographed. Identification of cestodes was based on Khalil et al. (1994).

The prevalence and intensity of infection were calculated based on Kabata (1985) as followed: Prevalence $=$ (total of infected fish/total of examined fish) $\times$ $100 \%$; Intensity $=$ total of parasites/total of infected fish.

\section{RESULTS}

The fish samples from captive system (ponds) were infected by Bothriocephalus acheilognathi, while no fish from the wild population was infected by this worm. A total of 16 fish samples from the captive system were infested by $B$. acheilognathi resulting in $53.33 \%$ prevalence and 8.06 of intensity. A total of 129 tapeworms were recorded during the study (Table 1).

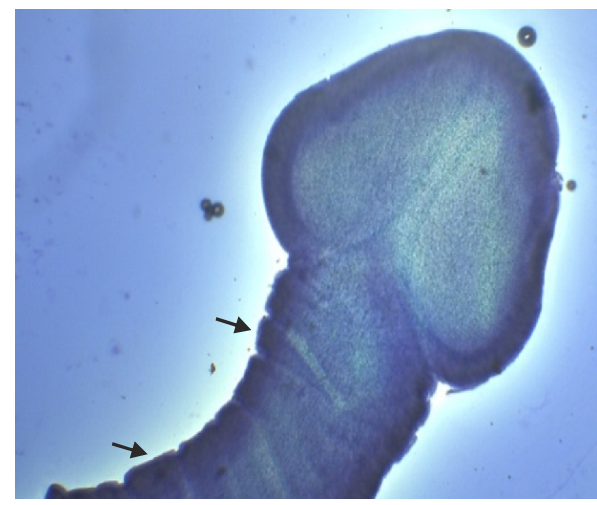

Fig. 1. Morphology of Asian fish tapeworm (Bothriocephalus acheilognathi) showing scolex and proglottids (arrows).

As recorded in this study and according to Scholz (1997), B. acheilognathi had specific characteristics: pyramid-shape scolex with a pair of bothria, segmented body (proglottids), no neck and no dorsal or ventral median furrow (Fig. 1).

\section{DISCUSSION}

This study revealed that the prevalence of Asian tapeworm in Tor tambra was relatively higher compared to that in fish from Bafra Fish Lake, the lower Kizilirmak Delta, Turkey (Ozturk \& Ozer, 2014) and Labeobarbus aeneus (Bertasso \& Avenant- 
Oldewage, 2005). However, the highest prevalence of Asian tapeworm was reported in Labeobarbus kimberleyensis (Bertasso \& Avenant-Oldewage, 2005), Cyprinella lutrensis (Heckmann et al., 1995) and Profundulus hildebrandi from the endorheic basin of San Cristobal de las Casas, Mexico (Velazquez-Velazquez et al., 2011).

We suggest that this was due to the poor sanitary condition of the pond. Our field observation indicates that the sludge from the deposition process of residual water and unconsumed feed and fish faeces at the pond bottom had reached a thickness of 20-25 cm. Based on Khalil et al. (1994), bottom sludge is the appropriate medium for growing of cestode larvae in the pond. Therefore, the prevalence of the endoparasite $B$. acheilognathi in local mahseer fish (T. tambra) was higher compared to that of ectoparasites as reported previously by Muchlisin et al. (2014). In addition, the prevalence of $B$. acheilognathi has probably a seasonal pattern with higher prevalence during the summer and lower in winter as recorded for Schizothorax niger (Zargar et al., 2012). Our study was conducted during the rainy season (winter), so, a higher prevalence would be expected during the dry season in Indonesia. Therefore, further study is needed to evaluate the real prevalence and intensity of this Asian tapeworm during the different seasons in the region.

The Asian tapeworm was probably introduced accidentally into the Nagan Raya region with infected common carp ( $C y$ prinus carpio) from Java Island, Indonesia in 2006 by Local Fisheries Affair (DKP). The common carp was also suspected as origin of $B$. acheilognathi infection in the endangered fish Profundulus hildebrandi in Mexico (Velazquez-Velazquez et al., 2011).
The study revealed that only fish sampled from aquaculture pond (captive system) were infected by tapeworm and no fish from wild river population had the tapeworm. According to Williams \& Williams (1996), the Asian tapeworm requires a copepod intermediate host and we speculate that aquaculture ponds provide ideal conditions for copepods and tapeworm transmission as mentioned earlier. According to Choudhury et al. (2013) streams are relatively less suitable for copepods growing and therefore $B$. acheilognathi was not found in the fish sample from stream as recorded in this study.

The Asian tapeworm had infected cyprinids in many countries of almost all continents and this is the first report from Aceh region, Indonesia. B. acheilognathi infection impairs fish health, body condition and growth (Marcogliese, 2008) and causes great economic losses in hatcheries and fish farms worldwide (Kuperman et al., 2001; Zargar et al., 2012). Therefore, the Asian tapeworm is a potential threat for aquaculture industry and a special attention to eradicate the invasiveness is needed.

\section{CONCLUSION}

The mahseer fish (T. tambra) sampled from aquaculture pond in Nagan Raya district, Indonesia was infected by the Asian fish tapeworm Bothriocephalus acheilognathi at a prevalence of $53.33 \%$ and intensity of 8.06 , while no fish sample from the Isiep River wild population was infected by this worm.

\section{ACKNOWLEDGMENTS}

The study was supported by Directorate General of Higher Education (DGHE), Department of National Education (Diknas), Republic of 
Indonesia through research grant of Master Plan Percepatan Pembangunan Ekonomi Indonesia (MP3EI), therefore the authors thank DGHE Diknas for supporting this study.

\section{REFERENCES}

Bertasso, A., \& A. Avenant-Oldewage, 2005. Aspects of the ecology of the Asian tapeworm, Bothriocephalus acheilognathi Yamaguti, 1934 in yellowfish in the Vaal Dam, South Africa. Onderstepoort Journal of Veterinary Research, 72, 207-217.

Boomker, J., F. W. Huchzermeyer \& T. W. Naude, 1980. Bothhriocephalosis in the common carp in the Eastern Transvaal. Journal of the South African Veterinary Association, 51, 263-264.

Choudhury, A. \& R. A. Cole, 2011. The Asian fish tapeworm Bothriocephalus acheilognathi. In: A Handbook of Global Freshwater Invasive Species, ed R. A. Francis, Earth Scan, London, U.K.

Choudhury, A., S. Zheng, G. P. de León, A. Martínez-Aquino, C. Brosseau \& E. Gale, 2013. The invasive asian fish tapeworm, Bothriocephalus acheilognathi Yamaguti, 1934, in the Chagres River/Panama Canal drainage, Panama. BioInvasions Records, 2, 99-104.

Heckmann, R. A., P. D. Greger \& R. C. Furtek, 1993. The Asian fish tapeworm, Bothriocephalus acheilognathi, in fishes from Nevada. Journal of Helminthological Society of Washington, 60, 127-128.

Hosseinifard, S. M., M. R. Youssefi, M. N. Amiri \& S. Shokrolahi, 2011. Bothriocephalus gowkongensis in the Neogobius fluviatilis fish of Alborz Dam from Iran. World Journal of Fish and Marine Sciences, 3, 260-262.

Justine, J. L., M. J. Briand \& R. A. Bray, 2012. A quick and simple method, usable in the field, for collecting parasites in suitable condition for both morphological and molecular studies. Parasitology Research, 111, 341-351.
Kabata, Z. 1985. Parasites and Disease of Fish Cultured in the Tropics. Tailor \& Francis, London, UK.

Khalil, L. F., A. Jones \& R. A. Bray, 1994. Key to the Cestoda Parasites of Vertebrates. $\mathrm{CAB}$ International, Wallingford, Oxon, UK.

Kuperman, B. I., V. E. Matey, R. N. Fisher \& M. L. Warburton, 2001. Bothriocephalus acheilognathi infection of fish in Southern California. In: Proceedings of the $76^{\text {th }} \mathrm{An}$ nual Meeting of the American Society of Parasitologists, June 29 - July 3, 2001, Albuquerque, New Mexico.

Marcogliese, D. J., 2008. First report of the Asian fish tapeworm in the Great Lakes. Journal of Great Lakes Research, 34, 566-569.

Muchlisin, Z. A., A. M. Munazir, Z. Fuady, W. Winaruddin, S. Sugianto, M. Adlim, N. Fadli \& A. Hendri, 2014. Prevalence of ectoparasites on mahseer fish (Tor tambra Valenciennes, 1842) from aquaculture ponds and wild population of Nagan Raya District, Indonesia. HVM Bioflux, 6, 148-152.

Muchlisin, Z. A., R. Hashim \& A. S. C. Chong, 2004. Preliminary study on the cryopreservation of tropical bagrid catfish (Mystus nemurus) spermatozoa: The effect of extender and cryoprotectant on the motility after short-term storage. Theriogenology, 62, 25-37.

Muchlisin, Z. A., A. S. Batubara, M. N. SitiAzizah, M. Adlim, A. Hendri, N. Fadli, A. A. Muhammadar \& S. Sugianto, 2015. Feeding habit and length weight relationship of keureling fish, Tor tambra Valenciennes, 1842 (Cyprinidae) from the western region of Aceh Province, Indonesia. Biodiversitas, 16, 89-94.

Ozturk, T. \& A. Ozer, 2014. Comparative invasive Asian tapeworm Bothriocephalus acheilognathi infection on lower Kizilirmak Delta Fishes. Journal of Academic Document for Fisheries and Aquaculture, 1, 1-7.

Salgado-Maldonado, G. \& R. F. PinedaLopez, 2003. The Asian fish tapeworm 
First report on Asian fish tapeworm (Bothriocephalus acheilognathi) infection of indigenous mahseer ...

Bothriocephalus acheilognathi: A potential threat to native freshwater fish species in Mexico. Biological Invasions, 5, 261268.

Scholz, T., 1997. A revision of the species of Bothriocephalus Rudolphi, 1808 (Cestoda: Pseudophyllidea) parasitic in American freshwater fishes. Systematic Parasitology, 36, 85-107.

Velazquez-Velazquez, E., D. Gonzalez-Solis \& G. Salgado-Maldonado, 2011. Bothriocephalus acheilognathi (Cestoda) in the endangered fish Profundulus hildebrandi (Cyprinodontiformes). Revista de Biología Tropical, 59, 1099-1104.

Waeschenbach, A., B. L. Webster \& D. T. J. Littlewood, 2012. Adding resolution to ordinal level relationships of tapeworms (Platyhelminthes: Cestoda) with large fragments of mt DNA. Molecular Phylogenetics and Evolution, 63, 834-847.

Williams E. H., Jr. \& L. B. Williams, 1996. Parasites of Offshore Big Game Fishes of Puerto Rico and the Western Atlantic. Puerto Rico. Department of Natural Environmental Resourses and University of Puerto Rico, Rio Piedras, Antillean College Press.

Yamaguti, S., 1934. Studies on the helminth fauna of Japan, part 4. Cestodes of fishes. Japanese Journal of Zoology, 6, 1-112.
Yera, H., R. Kuchta, J. Brabec, F. Peyron, \& J. Dupouy-Camet, 2013. First identification of eggs of the Asian fish tapeworm Bothriocephalus acheilognathi (Cestoda: Bothriocephalidea) in human stool. Parasitology International, 62, 268-271.

Zargar, U. R., M. Z. Chishti, A. R. Yousuf \& F. Ahmed, 2012. Infection level of the Asian tapeworm (Bothriocephalus acheilognathi) in the cyprinid fish, Schizothorax niger from Anchar Lake, relative to season, sex, length and condition factor. $P a-$ rasitology Research, 110, 427-435.

Paper received 17.11.2014; accepted for publication 13.03.2015

\section{Correspondence:}

Prof. Dr. Muchlisin Z. A., S.Pi, M.Sc

Department of Aquaculture,

Faculty of Marine and Fisheries,

Syiah Kuala University,

Banda Aceh 23111, Indonesia,

e-mail: muchlisinza@unsyiah.ac.id 